\title{
КТО НАРУШИЛ ЭТНИЧЕСКОЕ РАВНОВЕСИЕ В РОССИИ?
}

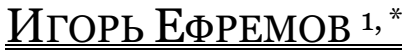

\begin{abstract}
Отклик на статью известного российского демографа Л.Л. Рыбаковского, посвященную этническим характеристикам депопуляции России. В условиях, когда суммарный коэффициент рождаемости в России опустился ниже уровня простого воспроизводства населения уже около полувека назад и при этом иельй ряд титульных народов России до сих пор не завершил демографический переход, актуальность такой статьи не вызывает сомнения. Автор выходит в своей статье на смежное поле демографии и этнологии, что усложняет его задачу. Он рассматривает проблему на глобальном, страновом и региональном уровнях, особенно сосредотачиваясь на ретроспективном описании исследуемых этнических и демографических процессов. Исследуется и демонстрируется важность их пространственных характеристик на уровне постсоветского пространства, России и ее регионов. Совмещение широко используемого в тексте «языка изифр»-обилия статистического материала - с эмоционально окрашенной оценкой исследуемых демографических и этнических процессов оживляет работу и не может оставить читателя равнодушным. Статья ставит перед читателем важные научные вопросы, но, к сожалению, дает меньше ответов.
\end{abstract}

Ключевые слова: депопулящия, миграциия, этническое равновесие, колонизаџия, ассимиляцฺия, перепись населения, репатриация, этнос, примордиализм.

В номере 4 (372) за 2015 г. одного из наиболее авторитетных российских журналов в области социологических наук «Социологические исследования» была опубликована статья доктора экономических наук, профессора, главного научного сотрудника Института социально-политических исследований РАН Леонида Леонидовича Рыбаковского «Депопуляция и ее этнические аспекты в России» [Рыбаковский 2015].

В условиях, когда суммарный коэффициент рождаемости в России опустился ниже уровня простого воспроизводства населения уже около полувека назад и при этом целый ряд титульных народов России до сих пор не завершил демографический переход, актуальность такой статьи не вызывает сомнения.

Л.Л. Рыбаковский - известный российский демограф - выходит в этой статье на смежное поле демографии и этнологии, что усложнило его задачу. Автор статьи рассматривает проблему на глобальном, страновом и региональном уровнях, особенно сосредотачиваясь на ретроспективном описании исследуемых этнических и демографических процессов. Исследуется и демонстрируется не меньшая, чем динамики вышеназванных процессов, важность их пространственных характеристик на уровне постсоветского пространства, России и ее регионов. Совмещение широко используемого в тексте «языка цифр» - обилия статистического материала - с эмоционально окрашенной оценкой исследуемых демографических и этнических процессов оживляет работу и не может оставить читателя равнодушным.

\footnotetext{
${ }^{1}$ РОССИЙСКАЯ АКАДЕМИЯ НАРОДНОГО ХОЗЯЙСТВА И ГОСУДАРСТВЕННОЙ СЛУЖБЫ ПРИ ПРЕЗИДЕНТЕ РОССИЙСКОЙ ФЕДЕРАЦИИ (РОССИЯ).

*E-mail: igorefremovnv@yandex.ru

СТАТЬЯ ПОСТУПИЛА В РЕДАКЦИЮ В ДЕКАБРЕ 2015 Г.
} 
Вопрос о том, что же такое депопуляция, может быть рассмотрен с разных точек зрения. Речь здесь может идти как исключительно о естественном движении населения, так и об общей динамике, включающей в себя итоги миграции. В свою очередь, начало убыли населения можно обнаружить как в момент перехода рождаемости за границу простого воспроизводства поколений при ее снижении, так и при превышении числа умерших над числом родившихся. В последнем случае временные рамки депопуляции могут быть сильно искажены возрастной структурой населения и краткосрочными явлениями (к примеру, кризисными для общества событиями).

В статье «Депопуляция и ее этнические аспекты в России» автор выбрал в качестве временных границ депопуляции годы превышения числа умерших над числом родившихся, о чем говорит указанная дата окончания депопуляции - «до 2013 г.». Общий же прирост населения России стал положительным еще в 2009 г. благодаря миграции. При этом суммарный коэффициент рождаемости уже в середине 1960-х годов опустился ниже уровня простого воспроизводства населения (с краткосрочным его достижением в 1980-х годах). Кроме того, согласно результатам Всероссийской переписи населения 2010 г., во всех поколениях россиянок, родившихся после 1940 г., среднее число рожденных детей, приходящихся на одну женщину, менее двух [Итоги всероссийской переписи населения... 2010b]. Исходя из этого, нам видится справедливым искать корни депопуляции в более далеких, нежели начало 1990-х, годах.

Рассматривая глобальный аспект российской депопуляции, автор приводит следующие данные: «Россия, занимая четвертое место в мире по численности населения в начале 1990-х гг., передвинулась в новом тысячелетии на девятое». К сожалению, приведенные данные не совсем верны: последний раз Россия (в современных границах) была на четвертом месте по величине населения лишь в 1970-х годах, после чего ее вытеснила Индонезия. К началу 1990-х годов Россия была уже шестой, пропустив вперед еще и Бразилию. К настоящему времени также Пакистан, Бангладеш и Нигерия имеют большее, чем Россия, население. Вполне возможно, что в статье на четвертом по людности месте в мире к началу 1990-х годов подразумевается весь Советский Союз, что, безусловно, правда. Но в таком случае потеря Россией лидирующих позиций вызвана не столько депопуляцией, сколько распадом СССР.

Автор справедливо отмечает, что «вследствие естественной убыли» «ускорилось сокращение доли России в мировом населении». Здесь нам хотелось бы немного пофантазировать о том, как могли бы развиваться события при отсутствии естественной убыли в описываемый период. В таком случае (при сохранении имевшихся величин миграционного прироста и нулевом естественном приросте) население России сейчас составляло бы приблизительно 156 млн человек вместо фактических (округленно) 147 млн. С 1992 по 2015 г. доля России в мировом населении сократилась с почти 2,8 до 2\%. А при реализации гипотетического сценария отсутствия естественной убыли доля россиян сократилась бы с тех же 2,8 до 2,15\%. Таким образом, глобальные демографические потери геополитического статуса России из-за депопуляции составили 0,15 процентного пункта. Эту величину трудно назвать значительной. Справедливости ради стоит отметить, что доля мирового населения, приходящаяся на демографически благополучные (по меркам развитых стран) США, также неуклонно сокращается. Уместно также вспомнить и более 
далекие годы. К началу XX века на острове Великобритания проживало около 2\% (удивительное совпадение) всего населения планеты. И эти 2\% фактически владели 20-ю процентами мирового населения, которое проживало на тот момент в их колониях. Тот факт, что нынешние 2\% мирового населения в лице россиян не установили контроль над пятой частью человечества, вряд ли свидетельствует лишь о недостатке в России демографического потенциала.

К ряду последствий депопуляции, помимо снижения трудноопределяемых «геополитического статуса» и «политического влияния», автор статьи причисляет также «сокращение его (государства) экономического и оборонного потенциала».

Достаточно простой и при этом доступный показатель экономического потенциала стран - валовой внутренний продукт - поможет пролить свет на связь депопуляции и экономического развития. За время депопуляции (1992 - 2013 гг. по версии автора статьи) валовой внутренний продукт, рассчитанный по паритету покупательной способности, в экономике России увеличился с 1 до 3,7 трлн долларов США [База данных Всемирного банка]. Аналогичная ситуация наблюдается также во многих других депопулирующих развитых странах.

Сравнивать оборонный потенциал стран в нынешних относительно мирных условиях сложнее. Тем не менее вооруженные силы требуют финансирования, и его объем может служить хорошей основой для сравнения. Так, по данным Стокгольмского института исследования мира, в 2014 г. депопулировавшая Россия оказалась на третьем месте в мире по военным тратам, уступая Китаю и США [Тренды мировых... 2014]. При этом в спину нам дышит Саудовская Аравия, которая со своим населением едва заметна на глобальном демографическом уровне. Но российский воин силен также смекалкой и боевым духом, которые, как известно, не купишь. Не говоря уже об инженерном и научном гении создателей российского оружия. Составители рейтинга «Глобальная военная мощь» ежегодно анализируют объемы и качество вооружения стран мира, исключая из анализа ядерный потенциал. Но даже и без боеголовок Россия в этом рейтинге стабильно держит второе место, оставляя далеко позади самые населенные страны мира - Китай и Индию [Рейтинг стран ... 2016]. Впрочем интересно не столько это, сколько, например, попадание почти в десятку стран с мощнейшими армиями мира (11-е место) крошечного Израиля с населением всего лишь около 8 млн человек. Небольшой демографический потенциал этой страны позволил не только создать процветающую экономику, но также и оборонный потенциал, который существенно больше, чем, к примеру, у четвертой по людности страны мира - Индонезии, второй по территории - Канады и седьмой по объему экономики Бразилии. Вероятно, в военных конфликтах XXI века стратегия закидывания врага трупами собственных солдат уже не работает.

Bсе это показывает, что гигантомания, даже демографическая, не гарантирует способность преодолеть экономические, военные, политические вызовы, стоящие перед государствами.

Переходя с глобального на общероссийский уровень описания проблемы, автор внимательно прочитанной нами статьи подмечает недооценку пространственных масштабов депопуляции общественным (научным и политическим) мнением из-за 
чрезмерной его сосредоточенности на обезлюдении исключительно азиатской части России. В действительности же депопуляция, согласно статье, отмечается в $80 \%$ субъектов РФ. Поэтому автор рекомендует государству сосредоточить свои усилия в первую очередь на решении проблем расселения населения, и лишь во вторую - проблем его динамики.

Согласно данным Росстата, в 2015 г. общая численность населения сократилась в $61 \%$ всех субъектов РФ [Оценка численности населения...], естественная убыль в 2014 г. (наиболее актуальные опубликованные данные) отмечалась в 49\% всех субъектов [Родившиеся, умершие...]. Нужно отметить, что в 1990-х и 2000-х годах число проблемных регионов было гораздо большим, хотя эта маленькая неточность нисколько не умаляет остроты проблем расселения населения России.

Автор статьи вводит термин «этническое равновесие», но не раскрывает его сущности. Аналогичный термин был введен антропологом и этнографом Сергеем Широкогоровым в 1920-х годах во время его исследований в Маньчжурии и имел отношение скорее к популяционной экологии, чем к этническим аспектам демографии [Ревуненкова, Решетов 2003]. В данной же статье лишь указывается, что этническое равновесие «создавалось в процессе длительного формирования единого российского государства». К концу советской эпохи действительно было достигнуто некоторое этническое равновесие. А именно: согласно переписи населения 1989 г. доля лидирующего по численности этноса - русских - в составе всего населения СССР снизилась по сравнению с предыдущей переписью и достигла $51 \%$. Таким образом, было практически достигнуто равновесие в численности русских и всех других этносов СССР, вместе взятых. Однако в дальнейшем автор статьи указывает на то, что снижение доли русских в современной России (80\% по переписи 2002 г. и 78\% по переписи 2010 г.) как раз и является нарушением этнического равновесия. Следовательно, для «равновесия» требуется как минимум сохранение доли крупнейшей этнической группы в структуре населения.

Неоднократное упоминание «мирного» сосуществования русских с некоторыми другими народами в течение многих веков, равно как и «мирное» присоединение части народов и территорий, дает основания предполагать, что под этническим равновесием в статье подразумевается мирное и относительно бесконфликтное сосуществование разных этнических групп внутри России, которое нарушилось депопуляцией, прежде всего, «государствообразующего этноса» - русских. Предпосылки такого подхода не совсем соответствуют суровой реальности былой колонизации этнических окраин России. Так, пятивековому действительно мирному сосуществованию русских и мордвы предшествовали сотни лет регулярных войн. Комментируя цитату из статьи: «Мирному проживанию вместе славянских и финно-угорских народов уже доброе тысячелетие», уместно будет упомянуть научные работы по истории, фокусирующиеся на данной теме и опровергающие приведенное выше утверждение автора (например, В.В. Фомин [2007]; Е.А. Федосеева [2006]; Е.Н. Мокшина [2013]; Н.Ф. Мокшин [1994: 232-237]; В.И. Молодин [2005: 67, 79, 83]). Колонизация Сибири также была настолько «мирной» и добровольной, что в фольклоре народов Севера русские до сих пор имеют негативные характеристики. К примеру, во время обрядовых танцев коренные жители надевают маски и объясняют духу мертвого зверя, что он убит русскими, которым дух соответственно должен отомстить [Кулемзин, Лукина 1992]. 
При этом было бы неправильно утверждать, что исключительно русские колонизаторы были жестокими убийцами. В действительности же насилие между разными этническими группами было абсолютной нормой в то время. Колонизируемые народы точно так же устраивали войны с соседями.

Колонизация, насильственная и ненасильственная ассимиляция оправдываются и объясняются в статье следующим образом: «славяне, находясь на более высоком уровне общественного развития, чем аборигены...»; «... (Латвия и Эстония) вообще не имели собственной государственности ... Эти страны были не захвачены Россией, а отвоеваны ею»; «Эти страны ... находились на более низком уровне общественного развития и были слабыми вследствие своих малых размеров ... (также) фокусировали на себе геополитические интересы (других) крупных держав». Достойной иллюстрацией «низкого уровня» развития является, к примеру, тот факт, что самые древние города на территории Российской империи и СССР были построены вовсе не руками славян и не на славянских землях. Еще один интересный факт: в XVII веке «не имевшее собственной государственности» герцогство Курляндии и Семигалии (современная западная и центральная Латвия) владело собственными колониями в Африке (современная Гамбия) и Америке (о. Тобаго в Карибском море) [Кенинш 1990: 99].

Но не только история достижения «этнического равновесия» описана в статье «Депопуляция и ее этнические аспекты в России». В положительном ключе отмечается взаимопроникновение народов в рамках союзных республик в СССР благодаря единому миграционному пространству. Упоминается и значимость миролюбивой национальной идеологии советского государства. В то же время далее в статье мы обнаруживаем данные об исходе русского населения с этнических окраин СССР с 1959 по 1989 г. в Закавказье и с 1979 по 1989 г. в Средней Азии. Это, а также известные кровавые этнические конфликты в этих регионах в конце 1980-х годов, наводит на мысль, что советская идеология вовсе не была такой эффективной. Очевидно, что межэтническая напряженность не была разрешена с помощью идеологии, а лишь накапливалась. Давление государства позволяло до поры до времени держать этнические конфликты в латентном состоянии, придав им так называемый «эффект сжатой пружины». Говоря о роли идеологии в межэтнических отношениях, можно также вспомнить, как советское государство помогло не только простым людям, но даже ученым-историкам «забыть» недостаточно мирные страницы взаимоотношений русского этноса с народами колонизируемых территорий. Так, ведущий советский энтограф 1930 1950-х годов профессор С.П. Толстов, создавая программу исторического отдела «руководящего теоретического органа партии» (журнала «Большевик») рекомендовал Управлению пропаганды и агитации советской коммунистической партии в 1944 г. пропагандировать «... ту большую положительную роль, которую оказало на развитие отсталых народов ... распространение элементов русской культуры», а также яростно клеймил советских историков, которые не могли «... уяснить наше советское понимание историзма и патриотического отношения к историческому прошлому», ошибочно, по его мнению, «... разоблачающих захватническую политику России» [Толстов 2007]. Профессор Толстов, как это было принято в то время, щедро сдабривал свои тексты цитатами из товарища Сталина. Этот эффективный менеджер, как известно, легко и результативно решал любые этнические проблемы, преподавая целым народам замечательные выездные 
уроки межнационального добрососедства в степях Казахстана, а также в тайге и тундре Сибири. Не потому ли советские идеология и пропаганда тех лет были так эффективны?

В статье отмечается важная роль в СССР «единого для страны русского языка». Нам же недоступность образования (особенно профессионального) на родном языке видится одним из основных орудий ассимиляции российских этносов и маргинализации их остатков. Тем не менее процесс колонизации и ассимиляции народов России в статье описывается скорее как полезный для установления «этнического равновесия». Следовательно, продолжение государством дискриминирующей языковой политики в отношении этнических меньшинств по такой логике помогает «нейтрализовать негативные последствия происходящих этнических ... процессов».

Полностью разделяя позицию автора о важности русского языка как языка межнационального общения, объединяющего народы России (а прежде народы СССР), мы все же полагаем, что он преувеличивает тяжесть последствий исхода русского населения из национальных республик. В статье описывается угрожающий процесс «систематического выдавливания государствообразующего народа России из национальных республик». В этой части наглядно демонстрируется заметное сокращение доли русских в населении ряда субъектов РФ за межпереписные периоды. Наиболее пугающая картина сложилась в Якутии, Тыве и всех северокавказских республиках, кроме Адыгеи. Но действительно ли Россия теряет эти национальные окраины? Мы проанализировали результаты переписей населения 2002 и 2010 г. в указанных регионах (таблица 1).

Таблица 1. Доля населения, владеющего русским языком, в отдельных регионах России по данным переписей населения 2002 и 2010 г., \%

\begin{tabular}{l|c|c|c}
\hline \multirow{2}{*}{ Субъект РФ } & \multicolumn{3}{|c}{ Доля населения, владеющего русским языком } \\
\cline { 2 - 4 } & 2002 & 2010 & изменение доли, п.п. \\
\hline Чеченская Республика & 81,4 & 91,8 & 10,4 \\
Республика Дагестан & 88,2 & 90,5 & 2,3 \\
Республика Ингушетия & 86,6 & 88,4 & 1,8 \\
Республика Северная Осетия & 96,3 & 97,0 & 0,7 \\
Кабардино-Балкарская Республика & 95,1 & 95,6 & 0,5 \\
Карачаево-Черкесккая Республика & 96,3 & 96,3 & 0 \\
Республика Саха (Якутия) & 93,3 & 92,3 & $-1,0$ \\
Республика Калмыкия & 99,3 & 97,6 & $-1,7$ \\
Республика Тыва & 87,8 & 84,7 & $-3,1$ \\
Дагестан, Чечня и Ингушетия вместе & 86,2 & 90,7 & 4,5 \\
\hline
\end{tabular}

Источники: [Итоги всероссийской переписи населения... 2010а; Итоги всероссийской переписи населения... 2002].

Как видно из таблицы 1, владение «единым для страны» русским языком в указанных республиках не только находится на высоком уровне, но даже растет в большинстве из них. Выполняя указание автора статьи «особо надо сказать о трех северокавказских республиках», мы также подсчитали этот показатель и для них вместе. Таким образом, несмотря на сокращение доли русского населения в республиках, распространение и влияние русского языка в них лишь растет. Возможно, этот инструмент межнационального общения окажет большее влияние на мир и стабильность, чем в советские годы оказывало присутствие сотен тысяч русских жителей. 
Описывая этническую динамику населения Кавказа с использованием переписных данных, необходимо поднять вопрос об их качестве. Результаты переписей населения 2002 и 2010 г. (прежде всего, в республиках Северного Кавказа, но также и в Москве, Башкортостане) многократно подвергались обоснованной критике. Среди их недостатков можно назвать, к примеру, вероятный двойной учет населения, выбывшего из регионов. Нельзя исключить и прямые фальсификации, направленные на искусственное завышение численности населения региона. Кроме того, в некоторых регионах местные власти, вероятно, пытались оказать влияние на результаты переписи в части ответов о национальной принадлежности [Богоявленский 2008; 2012]. Таким образом, с учетом языковой ситуации разбалансировка «этнического равновесия» на Северном Кавказе может оказаться совсем не такой катастрофичной, как описывает автор статьи.

Анализируя результаты переписи населения 2010 г., Л.Л. Рыбаковский указывает на «ускорение темпов сокращения ... доли основного этноса в населении России» по сравнению с итогами переписи 2002 г. В частности, в статье сообщается, что «за 8 лет доля русских уменьшилась почти на 4,9 млн человек». Даже если пройти мимо не совсем обычного измерения доли в млн человек, такое прочтение результатов переписи выглядит немного поверхностным. Как нами уже отмечалось выше, качество проведения переписей оставляло желать лучшего. Особенно это касается переписи 2010 г. В таблице 2 мы привели данные обеих переписей для дальнейшего анализа.

Таблица 2. Некоторые данные переписей населения России 2002 и 2010 г. по национальному составу населения, тыс. чел.

\begin{tabular}{|c|c|c|}
\hline & 2002 & 2010 \\
\hline Все население & 145167 & 142857 \\
\hline в том числе русские & 115889 & 111017 \\
\hline национальность не указана & 1461 & 5629 \\
\hline в том числе отказ от ответа & н.д. & 584 \\
\hline
\end{tabular}

Примечание: н.д. - нет данных.

Источники: [Итоги всероссийской переписи населения... 2010а; Итоги всероссийской переписи населения... 2002].

Как видно из таблицы 2, в разы выросла доля жителей России, чья этническая («национальная» в терминах переписи) принадлежность не указана вовсе. Если в 2002 г. такие жители составили 1\%, то в 2010 г. уже 3,9\%. Несмотря на сокращение абсолютного числа русских за межпереписной период, доля их от всего населения, указавшего свою национальность, немного выросла с 80,64 до 80,9\%. Но согласно автору статьи «уменьшение почти на 9 млн человек ... русского народа» «представляет питательную среду для ... национализма». Следовательно, опасаясь русского национализма, многочисленные представители этнических меньшинств, «систематически выдавливающие» русских, могли отказаться от сообщения своей национальности переписчику. Именно это, казалось бы, может объяснить такой рост доли переписанного населения без указания этничности. Но в действительности около $90 \%$ этого населения вопрос о национальной принадлежности в 2010 г. вообще не задавался, так как многие жители были переписаны по административным источникам, в которых нет таких сведений. А значит, число скрывающих свою национальность представителей этнических меньшинств даже в худшем случае не превысило 584 тыс. человек. Исходя из этого и из 
разумного допущения, что переписанные заочно жители России по национальной принадлежности распределены аналогично указавшим свою этничность, мы подсчитали примерную общую численность русских по переписям 2002 и 2010 г. Она составила 117,1 млн человек в 2002 г. и 115,1 млн в 2010 г. Таким образом, наиболее вероятно, что численность русских в этот межпереписной период сократилась на 2 млн человек или почти на 1,7\%, тогда как все население страны сократилось на 2,3 млн человек или на 1,6\%. Эти результаты входят в противоречие с уже упоминавшимися выводами статьи, согласно которым между переписями 2002 и 2010 гг. «доля русских уменьшилась почти на 4,9 млн человек».

В статье неоднократно указывается важная роль миграции в установлении или нарушении «этнического равновесия». По большому счету речь идет о репатриации (здесь и далее мы условно используем данный термин, подразумевая лишь прирост русского населения России в международном миграционном обмене) русских из бывших республик СССР. Несмотря на эту важность, в России «с 2008 г. прекращен учет национального состава мигрантов». Поэтому автор вынужден лишь приблизительно сообщить читателям численность русских, прибывших на постоянное место жительства между переписями населения - «70-80 тысяч человек». Эта оценка кажется странной. Автор прав в том, что учет национального состава мигрантов с 2008 г. был прекращен, но ведь до этого он велся. В таком доступном источнике как «Демографический ежегодник России» за 2008 г. можно без труда найти информацию, согласно которой миграционный прирост русских только за 2003-2007 гг. составил 242 тыс. человек [Демографический ежегодник 2008: 500], и наверняка он не прекратился и после этого. Если предположить, что его величина на протяжении трех лет до переписи населения в конце 2010 г. равнялась среднегодовой за 2003-2007 гг., то за весь межпереписной период он должен был составить 387 тыс. человек.

До известной степени эти данные можно проконтролировать, благодаря тому, что, к счастью, есть еще как минимум одно крупное постсоветское государство, которое очень ответственно относится к этнической принадлежности своих жителей - Казахстан. Мы позволили себе использовать данные статистики этой страны (и других стран постсоветского пространства), являющейся крупным миграционным партнером России, и тоже попытались сделать приблизительные оценки русских репатриантов в указанный период. Комитет по статистике министерства национальной экономики Казахстана публикует данные о национальном (этническом) составе мигрантов, в том числе по отдельным странам, включая Россию. Анализ этих данных показал, что с 2003 по 2010 г. в миграционном обороте с Россией Казахстан потерял в сумме 156,3 тыс. русских [Архив бюллетеней...]. Следует добавить, что при любом качестве учета миграции выбытия регистрируются хуже прибытий, а значит, это число должно быть еще больше. Как видно, одни лишь казахстанские русские репатрианты с лихвой перекрывают оценки автора статьи. Мы пошли дальше и посчитали, какой могла быть миграционная убыль русского населения в странах СНГ в обмене с Россией, исходя из численности имеющейся в начале 2000-х годов русской диаспоры в этих странах, Казахстанских данных и допущения, что исход русских на историческую родину из других стран СНГ имел приблизительно такую же интенсивность, как в Казахстане. Для этого мы собрали данные по национальному составу населения наиболее близких к 2002 г. переписей населения в ряде стран. Исходя из 
данных переписи населения Казахстана 1999 г. и приведенных выше данных текущего учета, миграционные потери русской диаспоры Казахстана составили приблизительно 3,5\% ее численности на начало 2000-х годов. В Узбекистане длительное время не проводились переписи населения, поэтому для него дана оценочная численность русского населения на начало 2000-х годов. Общие данные о русской диаспоре СНГ приведены в таблице 3.

\section{Таблица 3. Численность русского населения отдельных стран по данным переписей} населения, млн

\begin{tabular}{l|c|c}
\hline Страна & Год переписи & Численность русских \\
\hline Украина & 2001 & 8,3 \\
Казахстан & 1999 & 4,5 \\
Белоруссия & 1999 & 1,1 \\
Киргизия & 1999 & 0,6 \\
Молдавия (включая Приднестровье) & 2004 & 0,37 \\
Туркменистан & 1995 & 0,3 \\
Азербайджан (без Нагорного Карабаха) & 1999 & 0,14 \\
Грузия (без Абхазии и Южной Осетии) & 2002 & 0,07 \\
Таджикистан & 2000 & 0,07 \\
Армения & 2001 & 0,015 \\
Узбекистан & & ок. 1 \\
Всего & & ок. 16,5 \\
\hline
\end{tabular}

Источники: [Алексеенко 2002; Максакова 2010; Мкртчян, Сарыгулов 2012; Население Приднестровья ... 2005; Национальный состав населения Украины...; Перепись населения Армении...; Результать переписи населения...; Тульский 2005; 2006; Туркмены составляют ... 2001; Этнические группы ...; Юнусов 2004].

Подсчитанный таким образом миграционный прирост русского населения России в обмене со странами СНГ за 2003-2010 гг. мог превысить 500 тыс. человек. Но не Казахстаном единым полнится русский народ. Поэтому мы нашли еще один способ приблизительно оценить этот репатриационный поток. База неперсонифицированных микроданных российской переписи населения 2010 г. позволяет нам выделить жителей, участвовавших в переписи, назвавших себя русскими и указавших место проживания за год до переписи в других странах. Таких русских иммигрантов, прибывших в течение одного лишь года, было 72081 человек. Добавим к ним 3,5\% переписанных, вероятно, заочно людей без указания этнической принадлежности и получим не менее 75 тыс. русских иммигрантов [База микроданных переписей... 2016]. Вышеназванные данные статистики Казахстана показывают, что в данный межпереписной период величина потока русских эмигрантов быстро убывала. Следовательно, мы можем предположить в указанные годы русскую иммиграцию в объеме большем, чем 600 тыс. человек. Существовала, безусловно, и эмиграция русских. Но в условиях продолжавшейся репатриации немцев, евреев и титульных народов постсоветских стран объем ее, вероятно, не превысил 300 тыс. человек, исходя из данных Росстата о международной миграции, показывающих в сумме около 450 тыс. выбывших в 2003-2010 гг. [Международная миграция]. Таким образом, мы можем оценить миграционный прирост русского населения России между переписями 2002 и 2010 г. как минимум в пределах 300-500 тыс. человек, что неплохо согласуется с данными Демографического ежегодника России, но значительно больше оценки автора статьи. Безусловно, помимо русских, и другие титульные народы России (татары, башкиры, чуваши, мордва и др.) широко расселены по осколкам империи и также частично 
переселяются на историческую родину. Но мы не стали их учитывать, так как своим появлением на российской земле они, как должно следовать из логики статьи, лишь усугубляют нарушение «этнического равновесия». Автор статьи сам указывает на важность репатриационного потока: «3 млн (русских) человек прибыли в Россию из нового зарубежья». Но делает это лишь для периода между переписями 1989 и 2002 г. Мы же убеждены, что миграция русских в Россию и в 2000-е годы, несмотря на падение интенсивности, оставалась крупным источником пополнения их численности.

В статье подробнейшим образом описана динамика численности и доли практически всех крупных народов России между переписями 1989, 2002 и 2010 г. Возвращаясь к утверждению автора: «такая динамика (уменьшение на 7,4\% между 1989 и 2010 гг.) русского народа представляет питательную среду для проявления различных форм национализма», хотелось бы привести цитаты из статьи, которые иллюстрируют эту динамику у других народов. «Помимо русских наиболее сильно сократили численность и долю ... карелы, коми-пермяки и коми, марийцы, мордва, удмурты и чуваши. Численность этих народов с 1989 г. по 2010 г. уменьшилась почти на 1,1 млн человек, а доля в населении России сократилась с 2,87 до 2,39\% или на $16,7 \%$. Исходя из логики автора, что «такая динамика» у русских - «питательная среда ... национализма», мы предполагаем, что у вышеназванных народов, депопулирующих намного быстрее русских, среда для регионального этнического национализма (и, как следствие, сепаратизма в национальных республиках) гораздо более питательна. Особенно ее, должно быть, подпитывает тот факт, что депопуляция этих народов достигает таких масштабов за счет ассимиляции (иначе в отсутствие войн и геноцида этим народам с относительно высокой в среднем рождаемостью было бы проблематично так сильно уменьшиться). В подтверждение приводим данные переписи населения 2010 г. о среднем числе рожденных детей на одну женщину названных национальностей в возрастах 30-44 года, т.е. тех женщин, пик рождаемости у которых пришелся на описываемый период депопуляции (рисунок 1).

Следуя далее логике статьи о питательных средах для национализма по аналогии с тем, что исправление динамики русского народа в России должно сделать среду национализма менее питательной, мы неизбежно приходим к выводу, что путь к минимизации риска национализма и сепаратизма в национальных республиках улучшение динамики численности соответствующих титульных народов в своих регионах. Следовательно, представителям этих народов в своих республиках необходимо приложить максимум усилий к «систематическому выдавливанию государствообразующего народа», то бишь русских (а также всех прочих не титульных), давя, таким образом, национализм в зародыше. В итоге мы пришли к противоречивым выводам о том, кто, кого и откуда должен выдавливать ради сохранения мира, согласия, территориальной целостности и «этнического равновесия». 


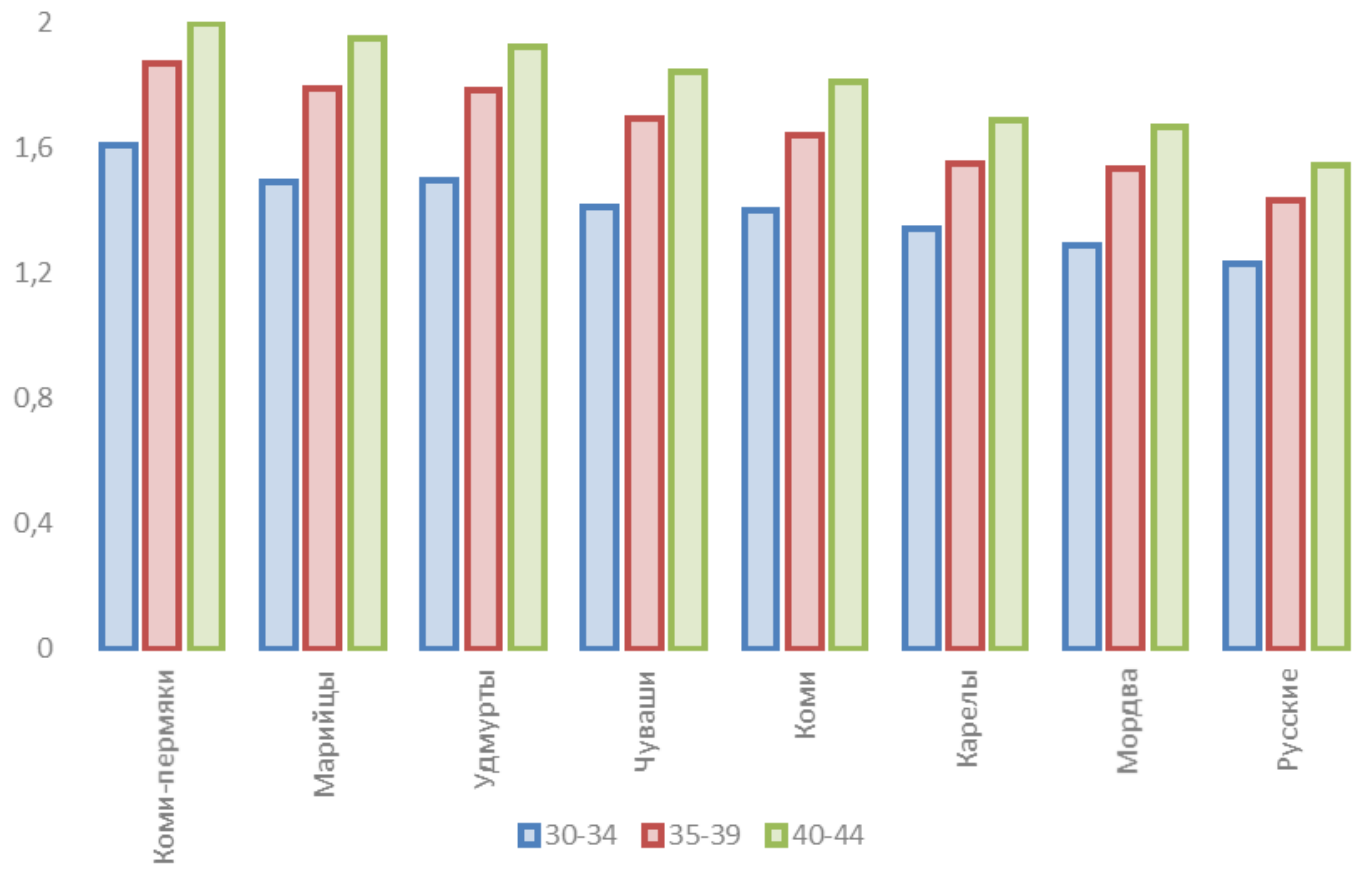

Рисунок 1. Среднее число рожденных детей на одну женщину соответствующего возраста по отдельным этническим группам согласно переписи населения России 2010 г.

Источник: [Итоги всероссийской переписи населения... 2010b].

Как показывает далее статья, в большинстве российских республик происходит «систематическое выдавливание» русских. Исключением стали лишь Карелия, Коми и Удмуртия, где доля русских выросла, а также Марий-Эл и Чувашия, где их доля стабильна. К сожалению, автор не углубляется в показатели «выдавливания» русских из республик, хотя было бы очень интересно разделить вклад «естественных» причин сокращения доли русского населения (разница с титульными народами в рождаемости, смертности, возрастной структуре) и миграции. Таким образом, можно было бы разделить регионы на те, из которых русских действительно выдавливают какие-либо факторы, и те, в которых русское население скорее «выдавливает» само себя в мир иной, чем в другие регионы.

В статье неоднократно упоминается влияние на этническую структуру населения добровольного изменения своей этнической принадлежности жителями России. Такие факты, как сказано, массово имели место во время переписи 1926 г., паспортизации населения, переписи 1939 г., между переписями 1989 и 2002 г.

Нельзя забывать и о сокрытии своей национальности многими представителями дискриминируемых этнических групп в СССР, что могло искусственно завышать долю русских. Напомним также, что программы переписей населения в России не допускают указания множественной этнической (национальной) принадлежности. Вполне возможно, что значительная часть упомянутых выше жителей России, отказавшихся назвать национальность переписчику, как минимум биэтничны и просто не смогли сделать свой выбор. Возникает вопрос, имеет ли моральное право государство (так или иначе влияющее на программу переписи населения) оказывать такое опосредованное давление на жителей в 
вопросах этнической идентичности? По нашему мнению, это не только неэтично, но и не в полной мере соответствует духу пункта 1 статьи 26 Конституции России, гласящей: «Каждый вправе определять и указывать свою национальную принадлежность. Никто не может быть принужден к определению и указанию своей национальной принадлежности». Насколько вообще разумно с позиции стремления к межнациональному согласию и «этническому равновесию» так или иначе вынуждать людей выбирать этничность в случаях, когда она множественная? Ведь демонстрация места межэтнических семейных союзов и их детей в населении России могла бы стать гораздо более действенным подтверждением братской дружбы народов, чем формалистское достижение и сохранение желаемого для государства соотношения разных этнических групп в населении. О масштабах и характеристиках этого явления можно узнать, к примеру, из работы Е.Л. Сороко [2014] о смешанных супружеских парах.

Возвращаясь к упоминанию в статье национализма, хотелось бы отметить следующую мысль автора: «то, что существует проблема русского этноса, невозможно отрицать». Удивляет отсутствие в статье заботы о проблемах других этносов многонациональной России. Как было указано самим автором, в стране есть народы, депопулирующие гораздо быстрее русского. Эти народы вдобавок стремительно ассимилируются. Тут уж русским грех жаловаться - никто их в России ассимилировать не способен. Если же идея о том, что первоочередного решения заслуживает лишь проблема «государствообразующего» этноса, захватит умы представителей менее преуспевающих народов, не приведет ли это к желанию тоже стать «государствообразующим» и очередной волне сепаратизма? Ведь, судя по всему, именно сепаратизма опасается автор статьи, напоминая нам о «выдавливании» русских из республик СССР незадолго до его распада и тут же указывая на повторение этого «выдавливания» уже в национальных республиках внутри России в настоящее время. Можно рассмотреть и важные составляющие демографических проблем этносов: рождаемость и смертность. Ряд народов России имеют сегодня едва ли не африканскую продолжительность жизни, ведь не русские в нашей стране лидеры в смертности. Неужели этот факт не заслуживает равного, с гораздо более низкой смертностью среди русского населения, внимания исследователей и государства? Л.Л. Рыбаковский в статье акцентирует внимание на проблемах ряда республик, чье титульное население еще имеет относительно высокую рождаемость. Эта высокая рождаемость вместе с наличием труднопреодолимых барьеров для межрегиональной мобильности вносит большой вклад в сегодняшнюю плачевную социально-экономическую ситуацию в данных субъектах. И именно в этих регионах автор статьи обнаружил самое сильное сокращение доли русского населения. Вероятно, решение демографических проблем этих этносов помогло бы не только им самим, но сохранило бы часть того самого «этнического равновесия» в республиках.

Теоретические подходы к проблемному полю статьи «Депопуляция и ее этнические аспекты в России» лежат, помимо демографической науки, в поле этнологии. Признавая свою недостаточную осведомленность в этой сфере, мы все же считаем, что основная часть идей и выводов автора строится на примордиалистском подходе к определению и исследованию этничности, утверждающем при первом приближении, что этносы неделимые сплоченные общности людей, объединенные рядом уникальных, в том числе 
биологических, признаков (подробнее об этнологических подходах, в частности примордиализме, см. Г.Л. Тульчинский [2011], В.А. Колосов [1998], Т.Г. Стефаненко [2009]). Но в рамках такой парадигмы нам представляется, что автор недооценивает роль русского языка в современных межнациональных отношениях в России, отмечая при этом его крайне высокую важность во времена СССР.

В тоже время отношение как к самим проблемам, поднятым в статье, так и к выводам автора, по нашему мнению, можно свести к известной дилемме «Человек для государства или государство для человека». Вероятно, автор статьи стоит ближе к позиции «Человек для государства». Это подтверждается, к примеру, его озабоченностью ранговым положением России среди стран мира по численности населения, геополитическим статусом страны, ее политическим влиянием, оборонным и экономическим потенциалом. Вряд ли жители процветающих, но малозаметных в глобальной политике стран сильно страдают от того, что их государство не может накладывать вето на решения Совета Безопасности $\mathrm{OOH}$, а также из-за своей неспособности, к примеру, «превратить США в радиоактивный пепел». Развивая известную идею «small is beautiful» в данном аспекте, хочется привести еще один интересный международный рейтинг. Центр мира и исследований конфликтов университета Сиднея разработал и составляет Глобальный индекс миролюбия. В последнем таком рейтинге (за 2015 г.) среди лидеров есть лишь одна страна с относительно большим населением - Япония (на 8-ом месте). Первая среди стран с ядерным оружием - Великобритания - на 39-ом месте. При этом в первой десятке рейтинга такие известные своей многонациональностью и терпимостью страны, как Канада, Австралия, Новая Зеландия. Россия же в этом рейтинге оказалась на 152-ом месте, и нашему миролюбию могут позавидовать лишь жители Северной Кореи, Пакистана и ряда стран с перманентными гражданскими войнами [Глобальный индекс миролюбия].

В то же время мы не претендуем на абсолютную правоту в этом вопросе. Очевидно, что интересы государства в формировании демографической и этнической политики тоже важны, а иногда они даже могут совпадать с интересами индивидов, живущих под его управлением и опекой.

Нельзя утверждать, что в вопросах национальной (этнической) политики в России государство самоустранилось и бездействует. При этом действия государства в этой сфере могут вызывать обоснованное беспокойство. Мы сомневаемся, что обеспокоенным нарушением «этнического равновесия» россиянам стоит удовлетвориться современной национальной политикой России, в рамках которой федеральный центр закрывает глаза на коррупцию, подбор государственных служащих по этническому (а то и по родственному) признаку, фактическое внедрение отдельных религиозных норм в качестве обязательного для всех жителей закона в ряде субъектов под предлогом якобы «национальных традиций» таких республик.

В завершении прочитанной нами статьи упоминалась «мина замедленного действия» - усиление локализации народов России в своих национальных «квартирах»титульных регионах - с одновременным исходом оттуда русского населения. В этой связи нам кажется, что «разминировать» хотя бы часть проблем русского и других этносов России 
помогло бы обеспечение реального равенства граждан, независимо от их этнической принадлежности.

В целом статья Л.Л. Рыбаковского после прочтения оставляет некоторое чувство незавершенности. Приведен масштабный подробный анализ преимущественно переписных данных об этнической динамике. Некоторые части статьи нагнетают мрачные опасения о судьбах России и русского народа. Из-за всего этого ожидается, что в конце статьи автор приведет спасительные рекомендации по восстановлению «этнического равновесия». Но, к сожалению, завершают статью лишь общие, хоть и верные, формулировки и благие пожелания: «нужна продуманная, согласованная между собой национальная и демографическая политика, которая могла бы нейтрализовать негативные последствия происходящих этнических и демографических процессов». При этом не указывается, в чем конкретно должна состоять такая политика. Статья «Депопуляция и ее этнические аспекты в России», как и полагается научному тексту, ставит перед читателем важные исследовательские вопросы. Но, к сожалению, дает гораздо меньше ответов.

В заключение хочется выразить надежду, что в светлом будущем в российском обществе этническая принадлежность станет настолько малозначимой на фоне превалирующей гражданской идентичности, что проблема нарушения «этнического равновесия» станет неактуальной.

\section{ЛИТЕРАТУРА}

Алексеенко А. (2002). О некоторых итогах переписи населения Казахстана // Демоскоп Weekly. №57-58. URL: http://www.demoscope.ru/weekly/2002/057/analit04.php (дата обращения: 06.01.2016).

Архив бюллетеней «Миграция населения». Комитет по статистике Министерства национальной экономики республики Казахстан. URL: http://stat.gov.kz (дата обращения: 06.01.2016).

База данных Всемирного банка. Всемирный банк. Вашингтон (CША). URL: http://data.worldbank.org/indicator/NY.GDP.PCAP.CD/countries (дата обращения: 06.01.2016).

База микроданных переписей населения России 2002 г. и 2010 г. М.: Федеральная служба государственной статистики.URL:

http://www.gks.ru/free_doc/new_site/perepis2010/croc/perepis_itogi1612.htm (дата обращения: 06.01.2016).

Богоявленский Д.Д. (2008). Все ли российские народы верно посчитали? // Демоскоп Weekly. №319-320. URL: http://demoscope.ru/weekly/2008/0319/tema01.php (дата обращения: 06.01.2016).

(2012). Перепись 2010: этнический срез // Демоскоп Weekly. №531532. URL: http://demoscope.ru/weekly/2012/0531/tema01.php (дата обращения: 06.01.2016).

Глобальный индекс миролюбия. Институт исследования экономики и мира. URL: http://www.visionofhumanity.org/\#/page/indexes/global-peace-index (дата обращения: 06.01.2016). 
Демографический ежегодник России 2008 (2008). Статистический сборник. М.: Федеральная служба государственной статистики.

Итоги всероссийской переписи населения 2002 (2002). Т.4. Национальный состав и владение языками, гражданство. М.: Федеральная служба государственной статистики PФ. URL: http://www.perepis2002.ru (дата обращения: 06.01.2016).

Итоги всероссийской переписи населения 2010 (2010a). Т.4. Национальный состав и владение языками, гражданство. М.: Федеральная служба государственной статистики. URL: http://www.gks.ru/free_doc/new_site/perepis2010/croc/perepis_itogi1612.htm (дата обращения: 06.01.2016).

(2010b). Т.10. Рождаемость. М.:

Федеральная служба государственной статистики РФ. URL:

http://www.gks.ru/free_doc/new_site/perepis2010/croc/perepis_itogi1612.htm (дата обращения: 06.01.2016).

Кенинш И. (1990). История Латвии. Рига: Изд-во Звайгзне.

Колосов В.А. (1998). «Примордиализм» и современное национально-государственное строительство // Полис. Политические исследования. №3: 95-106.

Кулемзин В.М., Н.В. Лукина (1992). Знакомьтесь: Ханты. Новосибирск.

Максакова Л. (2010). Узбекистан в системе международных миграций // Демоскоп Weekly. №415-416. URL: http://demoscope.ru/weekly/2010/0415/analit03.php (дата обращения: 06.01.2016).

Международная миграция. М.: Федеральная служба государственной статистики РФ. URL:

http://www.gks.ru/wps/wcm/connect/rosstat_main/rosstat/ru/statistics/population/demograph у (дата обращения: 06.01.2016).

Мкртчян Н., Б. Сарыгулов (2012). Изменение этнического состава населения Кыргызстана // Демоскоп Weekly. №531-532. URL: http://demoscope.ru/weekly/2012/0531/analit06.php (дата обращения: 06.01.2016).

Мокшин Н.Ф. (1994). Мордва // Народы России. Энциклопедия / Гл. ред. В.А. Тишков. М.: Большая российская энциклопедия.

Мокшина Е.Н. (2013). Мордовский народ в русских летописях и других письменных источниках средневековья // Социально-политические науки. №1: 27-30

Молодин В.И. (2005). История и культура Хантов. Томск: Изд-во Томского университета.

Население Приднестровья по переписи 2004 года (2005) // Демоскоп Weekly. URL: http://www.demoscope.ru/weekly/2005/0213/panorm01.php\#2 (дата обращения: 06.01.2016).

Национальный состав населения Украины по данным переписей населения.

Государственный комитет статистики Украины. URL:

http://2001.ukrcensus.gov.ua/rus/results/nationality_population/graphic (дата обращения: 06.01.2016).

Оценка численности населения на 1 января 2016 года и в среднем за 2015 год.

Федеральная служба государственной статистики РФ. URL:

http://www.gks.ru/wps/wcm/connect/rosstat_main/rosstat/ru/statistics/population/demograph y/ (дата обращения: 06.01.2016).

Перепись населения Армении 2001 г. Национальная статистическая служба Республики Армения. URL: http://www.armstat.am/en/?nid=585 (дата обращения: 06.01.2016). 
Ревуненкова Е.В., А.М. Решетов (2003). Сергей Михайлович Широкогоров // Этнографическое обозрение. №3: 100-118.

Результаты переписи населения республики Беларусь 2009 г. Национальный статистический комитет республики Беларусь. URL: http://census.belstat.gov.by/pdf/BOOK-ru-RU.pdf (дата обращения: 06.01.2016).

Рейтинг стран по военной силе (2016). Глобальная огневая мощь. URL: http://www.globalfirepower.com/countries-listing.asp (дата обращения: 06.01.2016).

Родившиеся, умершие и естественный прирост населения по субъектам Российской Федерации. М.: Федеральная служба государственной статистики PФ. URL: http://www.gks.ru/bgd/regl/B15_16/Main.htm (дата обращения: 06.01.2016).

Рыбаковский Л.Л.(2015). Депопуляция и ее этнические аспекты в России // Социс. №4:1828.

Сороко Е.Л. (2014). Этнически смешанные супружеские пары в Российской Федерации // Демографическое обозрение. №4: 96-123

Стефаненко Т.Г. (2009). Этническая идентичность: от этнологии к социальной психологии // Вестник Московского университета. Серия 14: Психология. №2: 3-17.

Толстов С.П. (2007). Докладная записка в Управление пропаганды и агитации ЦК ВКП(б) от 28 августа 1944 г. // Этнографическое обозрение. №5: 163-166

Тренды мировых военных расходов. 2014 г. (2014). Стокгольмский международный институт исследования мира. URL: http://books.sipri.org/product_info?c_product_id=496 (дата обращения: 04.01.2016).

Тульский М. (2005). Итоги переписи населения Таджикистана 2000 года: национальный, возрастной, половой, семейный и образовательный составы // Демоскоп Weekly. №191-192. URL: http://demoscope.ru/weekly/2005/0191/analit05.php (дата обращения: 06.01.2016).

(2006). Некоторые итоги переписи 2004 г. в Молдавии // Демоскоп Weekly. №249-250. URL: http://www.demoscope.ru/weekly/2006/0249/analit08.php (дата обращения: 06.01.2016).

Тульчинский Г.Л. (2011). Национальная идентичность и социально-культурные технологии ее формирования // Философские науки. №7: 23-28.

Туркмены составляют 91\% населения Туркмении (2001) // Демоскоп Weekly. URL: http://demoscope.ru/weekly/037/evro010.php (дата обращения: 06.01.2016).

Федосеева Е.А. (2006). Межнациональные отношения в эпической поэзии Мордвы // Регионология. №4: 394-403.

Фомин В.В. (2007). Пургасова Русь // Вопросы истории. №9: 3-17.

Этнические группы по основным административно-территориальным единицам Грузии. Национальное статистическое бюро Грузии. URL:

http://www.geostat.ge/cms/site_images/_files/english/census/2002/03\%20Ethnic\%20Compos ition.pdf (дата обращения: 06.01.2016).

Юнусов А. (2004). Этнический состав Азербайджана (по переписи 1999 года) // Демоскоп Weekly. №183-184. URL: http://demoscope.ru/weekly/2004/0183/analit05.php (дата обращения: 06.01.2016). 


\title{
WHO HAS UPSET THE ETHNIC BALANCE IN RUSSIA?
}

\section{IGOR EFREMOV1, *}

\begin{abstract}
Comments on the article "Depopulation and its ethnical aspects in Russia" written by the noted Russian demographer Leonid L. Rybakovskiy. Given a situation in which the total fertility rate in Russia has been below the replacement rate for about the past fifty years, in which, moreover, a number of ethnic groups have still not completed the demographic transition, the topicality of such an article is clear. The author here is working in the contiguous fields of demography and ethnology, which makes his task much harder. He studies the problem on a global, country and regional level, with a special focus on a historic description of the relevant demographic and ethnic processes, of which the author shows both the dynamics and the spatial aspects. The combination of statistics and an emotionally charged assessment of demographic and ethnic processes bring the paper alive in a way which can leave no reader indifferent. The article asks many important research questions, but unfortunately gives fewer answers.
\end{abstract}

Key words: depopulation, migration, ethnic balance, colonization, assimilation, population census, repatriation, ethnos, primordialism.

\section{REFERENCES}

Alekseenko A. (2002). O nekotorykh itogakh perepisi naseleniya Kazaxstana [Some results of the Kazakhstan population census] // Demoscope Weekly. №57-58. URL:

http://www.demoscope.ru/weekly/2002/057/analit04.php (accessed: 06.01.2016).

Arkhiv byulletenej "Migraciya naseleniya" [Archive of "Population migration" bulletins].

Komitet po statistike Ministerstva nacional'noj e'konomiki respubliki Kazakhstan [Ministry of national economy of the republic of Kazakhstan]. URL: http://stat.gov.kz (accessed: 06.01.2016).

Baza dannykh Vsemirnogo banka [World Bank database]. Vsemirnyj bank [World Bank]. Washington, USA. URL: http://data.worldbank.org/indicator/NY.GDP.PCAP.CD/countries (accessed: 06.01.2016).

Baza mikrodannykh perepisej naseleniya Rossii 2002 g. i 2010 g [Russian population 2002 and 2010 censuses microdata database]. Federal'naya sluzhba gosudarstvennoj statistiki RF [Russian Federal state statistics service]. Moscow. URL: http://www.gks.ru/free_doc/new_site/perepis2010/croc/perepis_itogi1612.htm (accessed: 06.01.2016).

Bogoyavlenskij D.D. (2008). Vse li rossijskie narody verno poschitali? [Whether all the Russians are accounted correctly?] // Demoscope Weekly. №319-320. URL:

http://demoscope.ru/weekly/2008/0319/tema01.php (accessed: 06.01.2016).

(2012). Perepis' 2010: e'tnicheskij srez [Census 2010: ethnic face] //

Demoscope Weekly. №531-532. URL: http://demoscope.ru/weekly/2012/0531/tema01.php (accessed: 06.01.2016).

Global'nyj indeks mirolyubiya [Global peace index]. Institut issledovaniya ekonomiki i mira [Economics and peace research institute]. URL:

http://www.visionofhumanity.org/\#/page/indexes/global-peace-index (accessed: 06.01.2016).

\footnotetext{
${ }^{1}$ The Russian Presidential Academy of National Economy and Public Administration (RANEPA) (Russia).

* CORRESPONDENCE igorefremovnv@yandex.ru

DATE RECEIVED: December 2015.
} 
Itogi vserossijskoj perepisi naseleniya 2002 [Results of the population census 2002] (2002). T.4. Nacional'nyj sostav i vladenie yazykami, grazhdanstvo [Vol. 4. Ethnic structure, languages and citizenship]. Moscow: Russian Federal state statistics service. URL: http://www.perepis2002.ru (accessed: 06.01.2016).

Itogi vserossijskoj perepisi naseleniya 2010 [Results of the population census 2010] (2010a). T.4. Nacional'nyj sostav i vladenie yazykami, grazhdanstvo [Vol.4. Ethnic structure, languages and citizenship]. Moscow: Russian Federal state statistics service. URL: http://www.gks.ru/free_doc/new_site/perepis2010/croc/perepis_itogi1612.htm (accessed: 06.01.2016).

Russian Federal state statistics service.. URL:

(2010b). T.10. Rozhdaemost' [Vol.10. Fertility]. Moscow: http://www.gks.ru/free_doc/new_site/perepis2010/croc/perepis_itogi1612.htm (accessed: 06.01.2016).

Keninsh I. (1990). Istoriya Latvii [History of Latvia]. Riga: Izd-vo Zvajgzne.

Kolosov V.A. (1998). "Primordialism" i sovremennoe nacional'no-gosudarstvennoe stroitel'stvo ["Primordialism" and present nation and state construction] // Polis. Politicheskie issledovaniya [Polis. Political research]. №3: 95-106.

Kulemzin V.M., N.V. Lukina. (1992). Znakom'tes': Khanty [Let's meet: Khanty]. Novosibirsk.

Maksakova L. (2010). Uzbekistan v sisteme mezhdunarodnykh migracij [Uzbekistan within the international migration system] // Demoscope Weekly. № 415-416. URL: http://demoscope.ru/weekly/2010/0415/analit03.php (accessed: 06.01.2016).

Mezhdunarodnaya migraciya [International migration]. Moscow: Russian Federal state statistics service. URL: http://www.gks.ru/wps/wcm/connect/rosstat_main/ rosstat/ru/statistics/population/demography (accessed: 06.01.2016).

Mkrtchyan N., B. Sarygulov (2012). Izmenenie etnicheskogo sostava naseleniya Kyrgyzstana [Changing of the Kyrgyzstan population ethnic structure] // Demoscope Weekly. №531-532. URL: http://demoscope.ru/weekly/2012/0531/analit06.php (accessed: 06.01.2016).

Mokshin N.F. (1994). Mordva // Narody Rossii. Enciklopediya [Population of Russia. Encyclopedia] / V.A. Tishkov, ed.. Moscow: Bol'shaya rossiaskaya enciklopediya [Great Russian Encyclopedia].

Mokshina E.N. (2013). Mordovskij narod v russkikh letopisyakh i drugix pis'mennykh istochnikakh srednevekov'ya [Mordva nation from the Russian chronicles and other medieval written sources] // Social'no-politicheskie nauki [Social and political sciences]. №1: 27-30.

Molodin V.I. (2005). ). Istoriya i kul'tura Khantov [History and culture of the Khantys]. Tomsk: Izd-vo Tomskogo universiteta.

Naselenie Pridnestrov'ya po perepisi 2004 goda (2005) [Transdnistria population according 2004 census] // Demoscope Weekly. URL:

http://www.demoscope.ru/weekly/2005/0213/panorm01.php\#2 (accessed: 06.01.2016).

Nacional'nyj sostav naseleniya Ukrainy po dannym perepisej naseleniya [Ethnic structure of Ukrainian population according population censuses]. Gosudarstvennyj komitet statistiki Ukrainy [Ukraine state statistics bureau]. URL:

http://2001.ukrcensus.gov.ua/rus/results/nationality_population/graphic (accessed: 06.01.2016).

Ocenka chislennosti naseleniya na 1 yanvarya 2016 goda i v srednem za 2015 god [Population estimated for January, 12016 and average 2015]. Federal'naya sluzhba gosudarstvennoj 
statistiki RF [Russian Federal state statistics service]. URL:

http://www.gks.ru/wps/wcm/connect/rosstat_main/rosstat/ru/statistics/population/demograph y/ (accessed: 06.01.2016).

Perepis' naseleniya Armenii 2001 g. [Armenia population census 2001]. Nacional'naya statisticheskaya sluzhba Respubliki Armeniya [National Statistics service of the Republic of Armenia]. URL: http://www.armstat.am/en/?nid=585 (accessed: 06.01.2016).

Revunenkova E.V., A.M. Reshetov (2003). Sergei Mixailovich Shirokogorov // Etnograficheskoe obozrenie [Ethnographic Review]. №3: 100-118.

Rezul'taty perepisi naseleniya respubliki Belarus' $2009 \mathrm{~g}$. [Results of the Belarus republic population census 2009]. Nacional'nyj statisticheskij komitet respubliki Belarus'[National statistics bureau of the Belarus republic]. URL: http://census.belstat.gov.by/pdf/BOOK-ruRU.pdf (accessed: 06.01.2016).

Rejting stran po voennoj sile [Countries ranking by military strength] (2016). Global'naya ognevaya moshh' [Global fire power]. URL: http://www.globalfirepower.com/countrieslisting.asp (accessed: 06.01.2016).

Rodivshiesya, umershie i estestvennyj prirost naseleniya po sub"ektam Rossijskoj Federacii [Numbers of births, deaths and natural increase by federal Subjects of Russia]. ]. Moscow: Russian Federal state statistics service.. URL: http://www.gks.ru/bgd/regl/B15_16/Main.htm (accessed: 06.01.2016).

Rybakovskiy L.L. (2015). Depopulation and its ethnical aspects in Russia [Depopulyatsiya i yeye eticheskiye aspekty v Rossii] // Sotsis [Social research]. № 4: 18-28.

Soroko E.L. (2014). Etnicheski smeshannye supruzheskie pary v Rossijskoj Federacii [Ethnically mixed families in the Russian Federation] // Demograficheskoe obozrenie [Demographic review]. №4: 96-123.

Stefanenko T.G. (2009). Etnicheskaya identichnost': ot etnologii k social'noj psikhologii [Ethnic identity: from ethnology to social psychology] // Vestnik Moskovskogo universiteta. Seriya 14: Psikhologiya [The Moscow University Herald. Series 14: Psychology]. №2: 3-17.

Tolstov S.P. (2007). Dokladnaya zapiska v Upravlenie propagandy i agitacii CK VKP(b) ot 28 avgusta $1944 \mathrm{~g}$ [Report to the Central Committee of the All-Union Communist Party (b) office of propaganda and agitation by August,24 1944] // Etnograficheskoe obozrenie [Ethnographic review]. №5: 163-166.

Trendy mirovykh voennykh rasxodov. $2014 \mathrm{~g}$. [Trends in world military expenditure, 2014] (2014). Stokgol'mskij mezhdunarodnyj institut issledovaniya mira [Stockholm International Peace Research Institute]. URL: http://books.sipri.org/product_info?c_product_id=496 (accessed: 06.01.2016).

Tulskiy M. (2005). Itogi perepisi naseleniya Tadzhikistana 2000 goda: nacional'nyj, vozrastnoj, polovoj, semejnyj i obrazovatel'nyj sostavy [The results of the Tajikistan population census 2000: ethnic, gender, family and education structure] // Demoscope Weekly. №191-192.

URL: http://demoscope.ru/weekly/2005/0191/analit05.php (accessed: 06.01.2016).

(2006). Nekotorye itogi perepisi 2004 g. v Moldavii [Some results of the Moldova census 2004] // Demoscope Weekly. №249-250. URL: http://www.demoscope.ru/weekly/2006/0249/analit08.php (accessed: 06.01.2016).

Tulchinskiy G.L. (2011). Nacional'naya identichnost' i social'no-kul'turnye texnologii ee formirovaniya [National identity and social-cultural technologies of its creating] // Filosofskie nauki [Philosophical sciences]. №7: 23-28. 
Turkmeny sostavlyayut 91\% naseleniya Turkmenii [91 percent of Turkmenistanian population are Turkmens] (2001) // Demoscope Weekly. URL:

http://demoscope.ru/weekly/037/evro010.php (accessed: 06.01.2016).

Fedoseeva E.A. (2006). Mezhnacional'nye otnosheniya v epicheskoj poezii Mordvy [International relations within Mordovian epic poetry] // Regionologiya [Regionology]. №4: 394-403.

Fomin V.V. (2007). Purgasova Rus // Voprosy istorii [Issues of History] №9: 3-17.

Etnicheskie gruppy po osnovnym administrativno-territorialnym edinicam Gruzii [Ethnic groups by main administrative-territorial units of Georgia]. Nacionalnoe statisticheskoe byuro Gruzii [National statistical bureau of Georgia]. URL:

http://www.geostat.ge/cms/site_images/_files/english/census/2002/03\%20Ethnic\%20Compos ition.pdf (accessed: 06.01.2016).

Yunusov A. (2004). Etnicheskij sostav Azerbajdzhana (po perepisi 1999 goda) [Ethnic structure of Azerbaijan population (according to 1999 census)] // Demoscope Weekly. №183-184. URL: http://demoscope.ru/weekly/2004/0183/analit05.php (accessed: 06.01.2016). 